\begin{tabular}{|c|c|c|}
\hline Beitr. Ent. & Keltern & ISSN 0005-805X \\
\hline $\mathbf{5 7}(2007) 2$ & S. $335-345$ & 21.12 .2007 \\
\hline
\end{tabular}

\title{
Two new species and additional records of "small"-eyed Quedius from the Eastern Mediterranean
}

\section{(Coleoptera: Staphylinidae: Staphylininae)}

\author{
With 29 figures
}

Volker Assing

\section{Summary}

Three Quedius species from the Eastern Mediterranean are (re-)described and illustrated: Quedius (Raphirus) endogeus sp. n. (Greece), Q. (Microsaurus) atricapillus Reitter, 1900 (Turkey), and Q. (M.) apfeli sp. n. (Cyprus). Additional records of some species of the subgenus Microsaurus Dejean, 1833 are reported, among them first records from Turkey, Lebanon, and Israel.

Key words

Coleoptera, Staphylinidae, Staphylininae, Quediina, Quedius, Palaearctic region, Eastern Mediterranean, taxonomy, new species, new records, endogean fauna.

New species

Quedius (Raphirus) endogeus sp. n., Q. (Microsaurus) apfeli sp. n.

\section{Zusammenfassung}

Drei Quedius-Arten aus dem östlichen Mittelmeerraum werden beschrieben bzw. redeskribiert und abgebildet: Quedius (Raphirus) endogeus sp. n. (Griechenland), Q. (Microsaurus) atricapillus ReITter, 1900 (Türkei) und Q. (M.) apfeli sp. n. (Zypern). Weitere Nachweise von Arten der Untergattung Microsaurus Dejean, 1833 werden gemeldet, darunter Erstnachweise aus der Türkei, dem Libanon und Israel.

\section{Introduction}

According to Herman (2001), the speciose genus Quedius Stephens, 1829 includes almost 800 species worldwide. However, there is evidence that the genus is not monophyletic and that at least some of the lineages from regions other than the Holarctic may refer to separate genera (Solodovnikov 2006). In the Palaearctic region, Quedius is represented by more than 530 species (Smetana 2004, Schülke unpubl.). One of the most prominent characters shared by almost all the species of the genus, except for those of the subgenus Microsaurus Dejean, 1833, is the large and bulging eyes, which occupy practically the whole side of the head. Reduced eye size is exceptional in subgenera other than Microsaurus, a subgenus whose species are often associated with subterranean or other dark habitats such as nests of mammals, birds, and social insects, hollow trees, caves, and the like. 
Material collected with subterranean traps in Greece and recently communicated to me by Pier Mauro Giachino (Torino) included a remarkable undescribed species of the subgenus Raphirus Stephens, 1829 with conspicuous adaptations to an endogean habitat. I use the opportunity to (re-)describe two species of Microsaurus from Cyprus and Turkey based on material made available to me by Wolfgang Apfel (Eisenach), Peter Sprick (Hannover), and Michael Schülke (Berlin), and to report additional records of some Microsaurus species from the Eastern Mediterranean, a region whose staphylinid fauna is still poorly known.

\section{Material and methods}

The material referred to below is deposited in the following collections:

$\begin{array}{ll}\text { NHMD } & \text { Natural History Museum of Denmark, Copenhagen (A. Solodovnikov) } \\ \text { cApf } & \text { private collection Wolfgang Apfel, Eisenach } \\ \text { cAss } & \text { author's private collection } \\ \text { cFel } & \text { private collection Benedikt Feldmann, Münster } \\ \text { cSch } & \text { private collection Michael Schülke, Berlin } \\ \text { cVai } & \text { private collection Dante Vailati, Brescia (via Pier Mauro Giachino) } \\ \text { cWun } & \text { private collection Paul Wunderle, Mönchengladbach }\end{array}$

The measurements in the descriptions are given in $\mathrm{mm}$ and abbreviated as follows:

$\begin{array}{ll}\text { EL } & \text { length of elytra from apex of scutellum to elytral hind margin } \\ \text { HL } & \text { head length from anterior margin of frons to neck } \\ \text { HW } & \text { maximal head width (across and including eyes) } \\ \text { ML } & \text { length of median lobe of aedeagus } \\ \text { PL } & \text { length of pronotum along median line } \\ \text { PW } & \text { maximal width of pronotum } \\ \text { TaL } & \text { length of metatarsus (claws not included) } \\ \text { TiL } & \text { length of metatibia (external aspect, from knee to insertion of first metatarsomere) } \\ \text { TL } & \text { body length from apex of mandibles to posterior margin of tergite VIII. }\end{array}$

\section{Species descriptions and additional records}

Quedius (Raphirus) endogeus sp. n. (Figs 1-10, 29) ${ }^{1}$

\section{Type material:}

Holotype ơ: "GR - Etolia-Akarnanía, Oros Oxia, 780 m, rd. Mandrini-Livadáki, 9.VI.06/10. VI.2007, lg. Giachino \& Vailati / Holotypus ơ Quedius endogeus sp. n. det. V. Assing 2007" (cAss). Paratypes: 2 우: same data as holotype (cVai, cAss); 3 o $^{\star}, 2$ 우: "GR - Evritanía, Oros Kokínias, above Livadáki, 1495 m, 9.VI.06/12.VI.2007, lg. Giachino \& Vailati" (cVai, cAss, NHMD).

\footnotetext{
${ }^{1}$ Results of the programm "Research Missions in the Mediterranean Bansin" sponsored by the World Biodiversity Association onlus. XXIII. contribution.
} 


\section{Description:}

Measurements (in $\mathrm{mm}$ ) and ratios (range, arithmetic mean; $\mathrm{n}=8$ ): HL: 0.98-1.12, 1.04; HW: 1.07-1.24, 1.16; PW: 1.27-1.45, 1.36; PL: 1.30-1.51, 1.41; EL: 0.92-1.06, 0.99; TiL: 1.24-1.48, 1.36; TaL: 1.03-1.15, 1.10; ML: 1.37-1.51, 1.46; TL: 7.2-9.1, 8.0; HW/HL: 1.07-1.13, 1.11; PW/HW: 1.14-1.21, 1.18; PL/PW: 1.02-1.04, 1.04; EL/PL: 0.67-0.73, 0.70; TiL/TaL: 1.19$1.29,1.23$.

Habitus distinctive (Fig. 1). Coloration: Head blackish; pronotum dark brown to blackish brown, with the lateral margins and sometimes also the anterior and posterior margins more or less narrowly reddish; elytra reddish to reddish brown; abdomen dark brown, with the posterior margins of tergites III-VI, the posterior third of tergite VII, and the posterior half of tergite VIII reddish; legs reddish; antennae dark brown, with the basal 3-4 antennomeres reddish.

Head (Fig. 2) slightly wider than long (see ratio HW/HL); dorsal surface with fine and very shallow transverse microsculpture. Dorsal puncturation (one side only, all punctures setiferous): 1 puncture at anterior margin of frons near antennal pit, 1 puncture at posterior margin of antennal pit; 1 puncture at dorsal margin of eye (approximately in the middle of length of eye); 1 temporal puncture at about $2 / 5$ the distance from posterior margin of eye to posterior margin of head; 1 puncture at about $4 / 5$ the distance from posterior margin eye to posterior margin of head. Eyes of reduced size (Fig. 3), slightly longer than postocular region in dorsal view. Antenna as in Fig. 4.

Pronotum of conspicuous shape (Fig. 2): slender, slightly wider than head and weakly oblong (see ratios $\mathrm{PW} / \mathrm{HW}$ and $\mathrm{PL} / \mathrm{PW})$; maximal width in anterior half, lateral margins in posterior $3 / 4$ almost straight and weakly converging in dorsal view. Dorsal rows composed of $1+2$ punctures. Microsculpture absent in dorsal median area, finely transverse in lateral areas.

Elytra distinctly shorter than pronotum (see ratio EL/PL); puncturation moderately dense, interstices on average as wide as or slightly wider than diameter of punctures; microsculpture absent. Scutellum impunctate and with distinct transverse microstriae. Legs slender (see measurements and ratio TiL/TaL).

Abdomen with very fine and shallow, almost obsolete transverse microsculpture and slightly iridescent; puncturation moderately dense, somewhat denser on anterior than on posterior tergites; posterior margin of tergite VII with palisade fringe.

$\sigma^{*}$ : posterior margin of sternite VIII with deep and rather broad posterior excision of triangular shape; aedeagus long and slender, paramere reaching apex of median lobe or extending slightly beyond it (Figs 5-10).

\section{Comparative notes:}

Based on the morphology of the aedeagus, this species refers to the group of Quedius limbatus (Heer 1839) and allied species of the the subgenus Raphirus. From all its Western Palaearctic consubgeners, $Q$. endogeus is readily distinguished by its conspicuous external appearance alone, especially the reduced eye size (somewhat resembling that of species of the subgenus Microsaurus) and the shape of the pronotum, which is more similar to that of species of Philonthus STEPHens, 1829 than to that of other Quedius species. The only other endogean Quedius known from Greece is Q. bernhaueri Rambousek, 1915, whose distribution is confined to Macedonia and northern Greece and which, according to Solodovnikov (2005), is doubtfully attributed to Microsaurus. From this species, $Q$. endogeus is at once separated by smaller body size, the more convex body ( $Q$. bernhaueri: pronotum, elytra, and abdomen conspicuously flattened), the more slender head and pronotum, the slightly larger eyes $(Q$. bernhaueri: eyes approximately as long as postocular region in dorsal view), the absence of microsculpture in the median dorsal area of the 
pronotum and on the elytra (in $Q$. bernhaueri with fine microreticulation), the distinctly longer and relatively broader elytra $(Q$. bernaueri less than 0.6 times as long as, and slightly narrower than pronotum), and the much more slender aedeagus. For illustrations of the habitus and the genitalia of Q. bernhaueri see Assing \& Wunderle (2001).

Etymology: The name (adjective) refers to the evidently endogean habitat of this species.

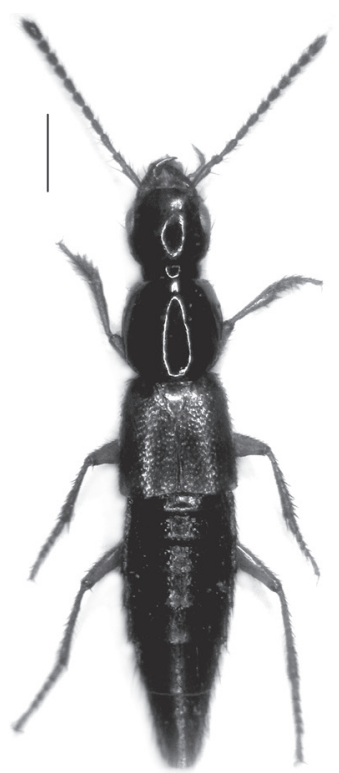

1

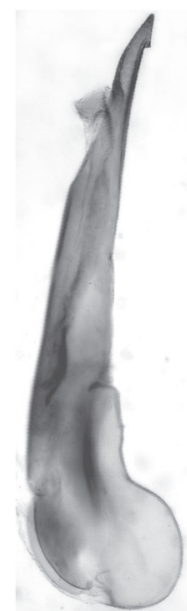

5

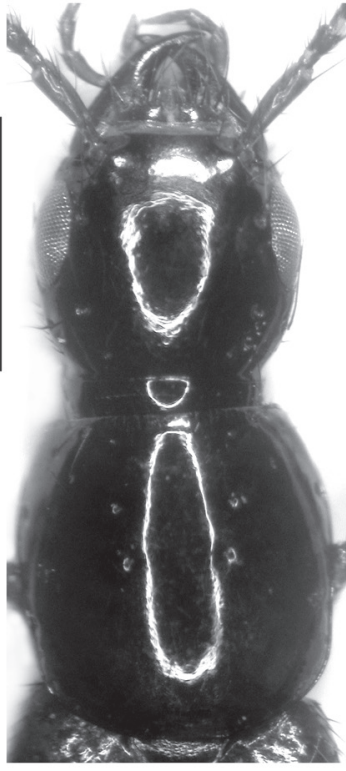

2

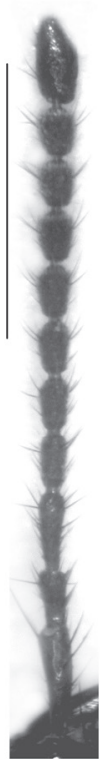

4

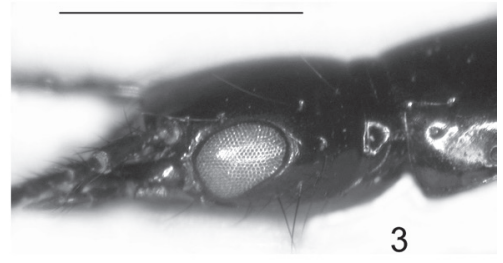

3

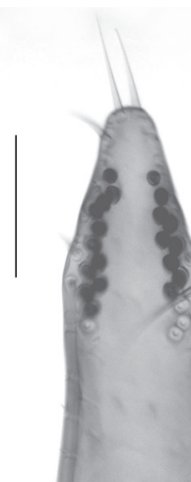

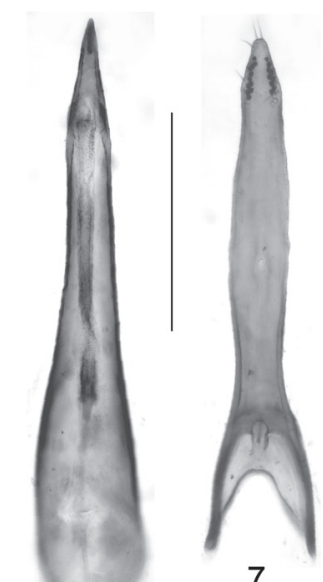

6

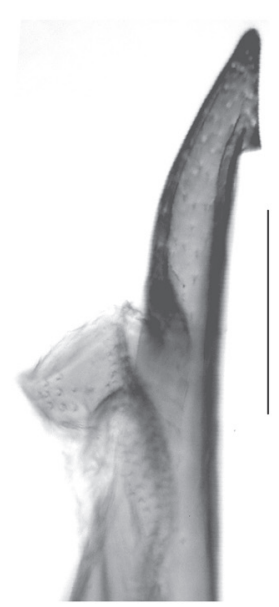

8

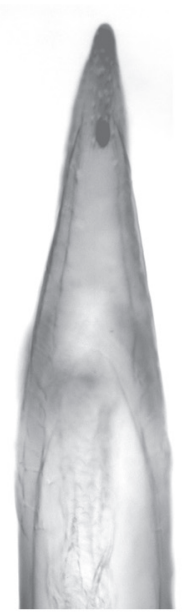

9

Figs 1-10: Quedius endogeus sp. n.: habitus (1); head and pronotum (2); head in lateral view (3); antenna (4); median lobe of aedeagus in lateral and in ventral view (5-6); paramere (7); apex of median lobe of aedeagus in lateral and in ventral view (8-9); apex of paramere (10). Scale bars: 1-4: 1.0 mm; 5-7: $0.5 \mathrm{~mm}$; 8-10: $0.1 \mathrm{~mm}$. 


\section{Distribution and bionomics:}

This remarkable species was discovered in two localities near the border between Evritanía and Etolia-Akarnanía, where the types were collected with subterranean pitfall traps baited with cheese at a depth of approximately $50 \mathrm{~cm}$ below the soil surface (Giachino pers. comm.). The locality at $1495 \mathrm{~m}$, a calcareous roadside slope, is illustrated in Fig. 29.

The circumstances of collection, the absence of previous records, as well as the conspicuous morphological adaptations - i. e. the reduced eye size, the derived shape of the pronotum, the short wings, and the long legs - leave little doubt that the species is confined to an endogean habitat.

\section{Quedius (Microsaurus) atricapillus REITTER, 1900 (Figs 11-19)}

Material examined: Turkey, Antalya: 2 exs., $16 \mathrm{~km}$ NE Demirtaş, $36^{\circ} 30^{\prime} \mathrm{N}, 32^{\circ} 20^{\prime} \mathrm{E}, 800-1100 \mathrm{~m}$, 26.V.2006, leg. Weigel (cApf, cAss); 1 ex., $18 \mathrm{~km} \mathrm{NE} \mathrm{Demirtaş,} \mathrm{pass,} 36^{\circ} 40^{\prime} \mathrm{N}, 32^{\circ} 23^{\prime} \mathrm{E}, 1550 \mathrm{~m}, 26 .+28$. V.2006, leg. Skale (cApf).

\section{Redescription:}

Measurements (in mm) and ratios (range; n=3): HL: 1.04-1.14; HW: 1.46 ( $\left.\mathrm{o}^{\star}\right), 1.23-1.30$ ( ( ) ; PW: 1.65-1.79; PL: 1.53-1.60;EL: 1.14-1.21;TiL:1.23-1.25;TaL:1.02-1.14;ML:1.21;TL:7.4-10.7;

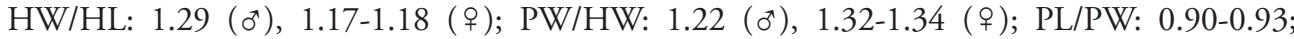
EL/PL: 0.72-0.76; TiL/TaL: 1.08-1.23.

Habitus as in Fig. 11. Conspicuously colourful species: Head black; pronotum and prosternum bright reddish; elytra reddish yellow; scutellum, mesosternum, and metasternum black; abdomen with segments III-VII and anterior third of segment VIII bright reddish and posterior two thirds segment VIII blackish; legs reddish; antennae blackish brown, with the basal 4 antennomeres reddish.

Head transverse, more so in $\sigma^{\star}$ than in 9 (see ratio HW/HL and Figs 12-13); anterior margin of frons broadly concave; dorsal surface with fine transverse microsculpture and rather sparse micropuncturation. Dorsal puncturation (one side only; all punctures setiferous): 1 puncture at anterior margin frons of near antennal pit, 1 puncture at posterior margin of antennal pit; dorsal margin of eye with 3 punctures, 2 of them near anterior margin of eye and one approximately in the middle of dorsal margin; 1 temporal puncture at about $1 / 3$ the distance from posterior margin of eye to posterior margin of head; 2 punctures near posterior margin of head. Eyes (Fig. 14) slightly longer than postocular region in dorsal view. Antenna as in Fig. 15.

Pronotum transverse and distinctly wider than head (see ratios PW/HW and PL/PW); maximal width approximately in the middle; lateral and posterior margins smoothly rounded (Figs 12-13). Dorsal rows composed of $1+2$ punctures; dorso-laterally without puncture behind long lateral seta. Microsculpture similar to that of head; whole surface with fine transverse microstriae.

Elytra wider and at suture somewhat shorter than pronotum (see ratio EL/PL); puncturation moderately dense, interstices on average wider than diameter of punctures; microsculpture absent (Figs 12-13). Scutellum impunctate and with distinct transverse microstriae. Hind wings fully developed. Legs of moderate length (see measurements and ratio TiL/TaL).

Abdomen only with traces of barely noticeable microsculpture; puncturation distinct and not very dense; posterior margin of tergite VII with palisade fringe.

$\mathrm{o}^{\text {: }}$ : posterior margin of sternite VIII with broad, rather shallow, and in the middle not distinctly acute posterior excision, on either side of middle with row of long black submarginal setae; aedeagus of distinctive morphology (Figs 16-19). 


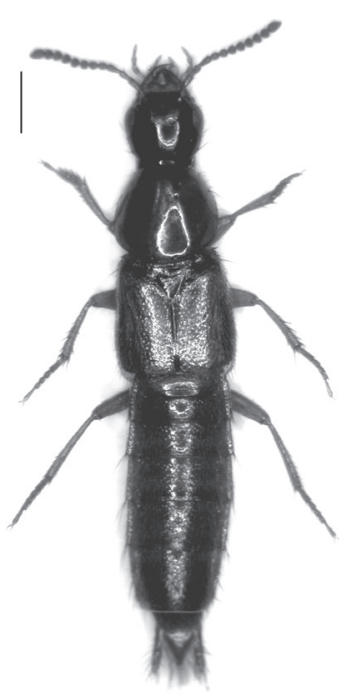

11

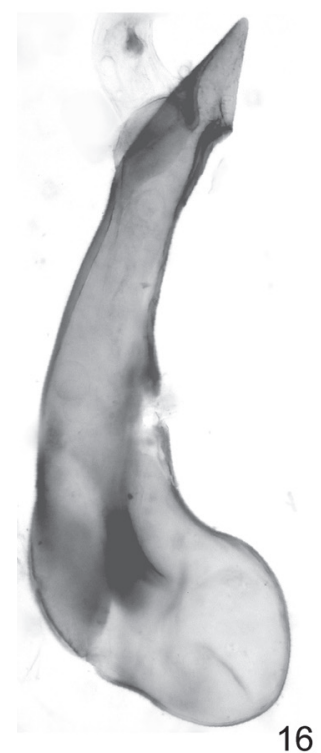

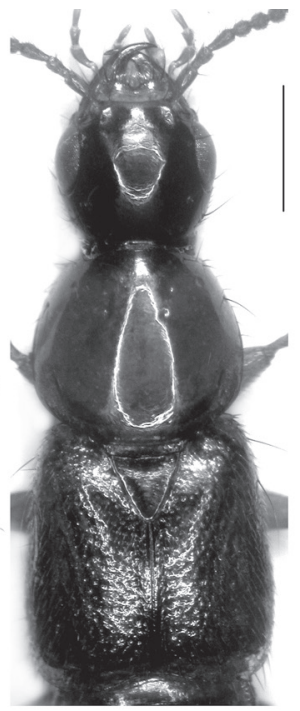

12

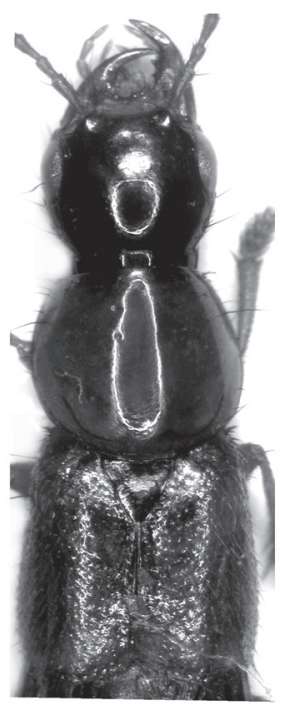

13

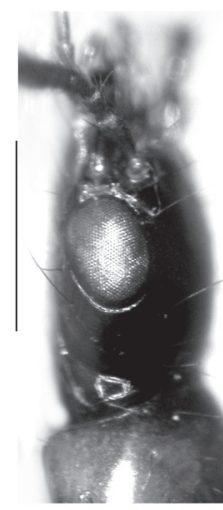

14

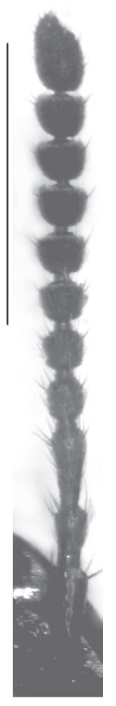

15

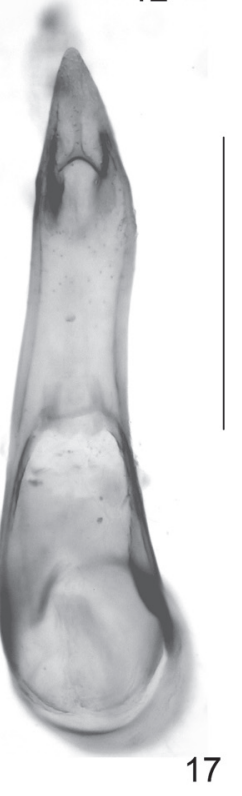

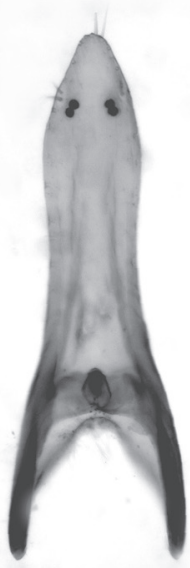

18

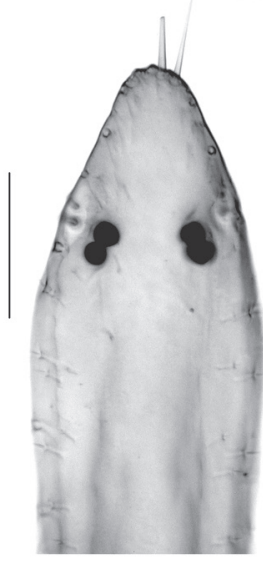

19

Figs 11-19: Quedius atricapillus ReitTer: o habitus (11); ㅇ forebody (12); o forebody (13); head in lateral view (14); antenna (15); median lobe of aedeagus in lateral and in ventral view (16-17); paramere (18); apex of paramere (19). Scale bars: 11-15: $1.0 \mathrm{~mm} ; 16-18: 0.5 \mathrm{~mm}$; 19: $0.1 \mathrm{~mm}$.

: posterior margin of sternite VIII broadly and weakly convex, row of submarginal setae black, but shorter than in $0^{*}$.

\section{Comparative notes:}

Among other Microsaurus species, Q. atricapillus is characterised especially by the distinctively bicoloured body and by the morphology of the aedeagus. The latter somewhat resembles that 
of $Q$. abietum both in shape and in chaetotaxy, but is distinctly smaller. For illustrations of the aedeagi of its Western Palaearctic consubgeners see CoIffait (1978).

\section{Distribution and bionomics:}

The species was originally described from several ["in einiger Anzahl"] syntypes from "Ober-Syrien: Akbes" (ReitTer 1900), which is probably identical to what is Akbez [=Akboz or Akbaz] in northern Antakya province, Turkey, today. Since no further records had been published, the previously known distribution was confined to Turkey, not to Syria (Herman 2001, Smetana 2004). The additional specimens listed above represent the first record after the original description. They were collected in two localities near Demirtaş, eastern Antalya province, southwestern Anatolia, at an altitude of about $800-1550 \mathrm{~m}$. One of the beetles is slightly teneral.

\section{Quedius (Microsaurus) nigrocaeruleus FAUVEL, 1876}

Material examined: Greece: 1 ex., Thessalia, Ossa Oros, 14.VII.2006, leg. Eifler (cAss).

The species was only recently reported from Greece for the first time (Assing 2006).

\section{Quedius (Microsaurus) fulgidus (FABRICIUS, 1793)}

Material examined: Turkey: $1 \mathrm{o}^{\star}$ [det. Schülke], Nevšehir, Avanos, 7.-10.VII.1983, leg. Dvořák (cSch).

According to Herman (2001) and Smetana (2004), this species is widespread in the Western Palaearctic region and has been reported from Turkey before.

\section{Quedius (Microsaurus) ochripennis (MÉNÉTRIÉs, 1832)}

Material examined: Greece: 2 exs., Thessalia, Ossa Oros, 14.VII.2006, leg. Eifler (cAss). Turkey: 1 o $^{\star}$, Antakya, N Belen Geçidi, 36 31'N, 36 $15^{\circ} \mathrm{E}, 1310 \mathrm{~m}$, 23.IV.2004, leg. Brachat \& Meybohm (cAss). Lebanon: $10^{\top}$, Ehden, Forest of Ehden, $34^{\circ} 18^{\prime} \mathrm{N}, 36^{\circ} 00^{\prime} \mathrm{E}, 1300-1650 \mathrm{~m}, 25 . \mathrm{V} .2006$, leg. Frenzel (cAss).

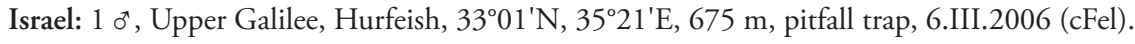

The species is widespread in the Western Palaearctic region and Middle Asia, but was previously unknown from Israel and Lebanon (Herman 2001, Smetana 2004). For additional records, including the first record from Greece, see Assing (2004).

\section{Quedius (Microsaurus) brevis ERICHSON, 1840}

Material examined: Greece: 4 exs., N Sérres, Vrontous, S Lailias, 1400 m, Formica nest, 25.V.1999, leg. Wunderle (cWun). Turkey: Kastamonu: 1 ex., Ilgaz Dağı, leg. Schubert (cAss).

The species is widespread in the Western Palaearctic region, but was previously unknown from Turkey (Herman 2001, Smetana 2004). For the recent first record from Greece see Assing (2006).

\section{Quedius (Microsaurus) xanthopus ERICHSON, 1839}

Material examined: Greece: 1 ex., Kavála, W-Rhodopi, N Skaloti, 1500-1600 m, 13.-14.VI.2002, leg. Brachat (cAss).

The species was recently reported from Greece for the first time (Assing \& WUNDERLE 2001). 


\section{Quedius (Microsaurus) abietum KIESENWETTER, 1858}

Material examined: Greece: Pelopónnisos: $3 \sigma^{\star} o^{\star}$, Taygetos, 1300 m, 7.VII.2005, leg. Eifler (cAss); 1 ㅇ, Taygetos, road to Prof. Ilias, 1100-1400 m, 16.VI.1996, leg. Wunderle (cWun); 2 o $^{\star} 0^{\star}, 14 \mathrm{~km}$ NE Lálas, $700 \mathrm{~m}$, oak forest, 4.X.2004, leg. Schawaller (cAss); $1 \mathrm{o}^{\text {* }}, 8 \mathrm{~km}$ NE Kalávryta, $650 \mathrm{~m}$, Platanus litter, 21.IX.2004, leg. Bense (cAss). Corfu: 1 \% , Pantokrator, litter of acorn and beech,25.IX.1994, leg. Wunderle (cWun). Kefallinia: 3 o $^{\star} o^{\star}, 1$ \% , peak of Enos, 1600 m, fir forest, 28.IX.1993, leg. Assing (cAss); $10^{\star}$, Enos, 1200-1600 m, 8.X.1992, leg. Sprick (cAss). Crete: 1 đ , Láki, 11.-18.V.1993, leg. Rydh (cAss).

Turkey: $1 \sigma^{\star}$, Antalya, Elmalı, 1200 m, 21.-28.V.1991, leg. Rydh (cWun); 1 ơ, 2 exs. [det. Schülke], Mersin, 15 km E Gülnar, Kayrak, 24.V.1995, leg. Bíža \& Koštál (cSch).

According to Coiffait (1978), Herman (2001), and Smetana (2004), the species is widespread in the Mediterranean, from Spain and Morocco in the west to Turkey in the east.

\section{Quedius (Microsaurus) cruentus (OLIVIER, 1795)}

Material examined: Greece: mainland: 2 exs., Thessalia, Ossa Oros, S Spilia, 3946'N, 22 $2^{\circ} 40^{\prime} \mathrm{E}, 1040 \mathrm{~m}$, fir forest, 22.VII.2004, leg. Assing (cAss). Pelopónnisos: 3 exs., Arkadia, Taygetos, Prof. Ilias, 750 m, IV.1999, leg. Wachtel (cAss); 1 ex., Taygetos, Neokhóri, 1100 m, mixed forest, 30.IX.2004, leg. Schawaller (cAss); 1 ex., Taygetos, E main peak, 1300-1500 m, 29.IX.2004, leg. Schawaller (cAss); 1 ex., Taygetos, 1300 m, 7.VII.2005, leg. Eifler (cAss); 2 exs., Panahaiko, 1000 m, mixed forest, 7.X.2004, leg. Bense (cAss); 1 ex., Kalavryta, 28.VI.2005, leg. Eifler (cAss); 3 exs., Aiyon, road to Kalavryta, 200-700 m, 29.VI.1994, leg. Angelini (cWun); 1 ex., Lámbia, 18 km NE Panópulos, 950 m, 5.X.2004, leg. Bense (cAss).

Quedius cruentus is one of the most widespread and common Microsaurus species in the Western Palaearctic region and has also been introduced in North America (Herman 2001, Smetana 2004).

\section{Quedius (Microsaurus) aetolicus KRAATZ, 1958}

Material examined: Turkey: $1 \sigma^{\star}$, Antalya, Akseki, 16.III.2000, leg. Esser (cAss).

The species was originally described from Greece, but later only reported from the Western Mediterranean and Western Europe (Coiffait 1978, Herman 2001, Smetana 2004). It is here reported from Turkey for the first time.

\section{Quedius (Microsaurus) apfeli sp. n. (Figs 20-28)}

\section{Type material:}

Holotype ơ: "W Zypern 2004, Umg. Statos-Agios Fotios, Obstwiese/Hang, leg. W. Apfel 30.IV. / Holotypus ơ Quedius apfeli sp. n. det. V. Assing 2007" (cAss). Paratypes: 1 o [slightly teneral]: "Cyprus - Troodos-Geb.; Cedar Valley $\rightarrow$ Tripylos, 1000-1360 m, 23.IV.95, Sprick \& Bauer" (cAss); 1 o: "West Zypern 2004, Paphos Forest, 16 km südlich von Pomos, Bachtal, leg. W. Apfel, 25.IV." (cApf); 3 o o o $^{\star} 1$ ㅇ: "Cyprus, Nicosia dist., Pafos Forest, Cedar Valley, $34^{\circ} 59^{\prime} 23^{\prime N}$, 3241'20"E, 1410 m, 13.VI.2004, leg. M. Homburg" (cSch, cAss, NHMD).

\section{Description:}

Measurements (in $\mathrm{mm}$ ) and ratios (range, arithmetic mean; $\mathrm{n}=7$ ): HL: 0.93-1.23, 1.10; HW: 1.09-1.53, 1.37 (o), 1.23-1.25, 1.24 ()); PW: 1.44-1.90, 1.72; PL: 1.32-1.67, 1.55; EL:0.95-1.21,1.12;TiL:1.09-1.42,1.27;TaL:0.90-1.25,1.10;ML:0.90-0.97,0.94;TL:8.5-10.5,9.4; HW/HL: 1.18-1.32, 1.25 (o ), 1.13-1.15, 1.14 (ㅇ); PW/HW: 1.23-1.32, 1.26 (o ), 1.33-1.38, 1.36 (ㅇ); PL/PW: 0.88-0.92, 0.90; EL/PL: 0.70-0.75, 0.72; TiL/TaL: 1.09-1.21, 1.16. 


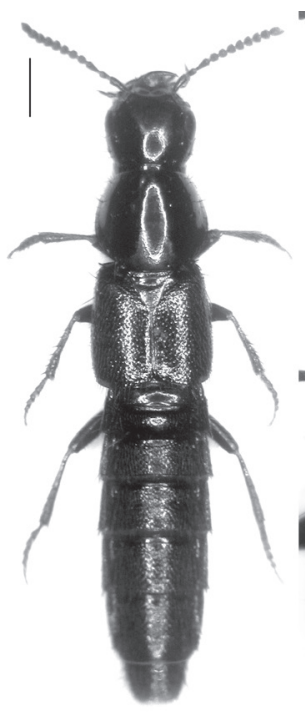

20

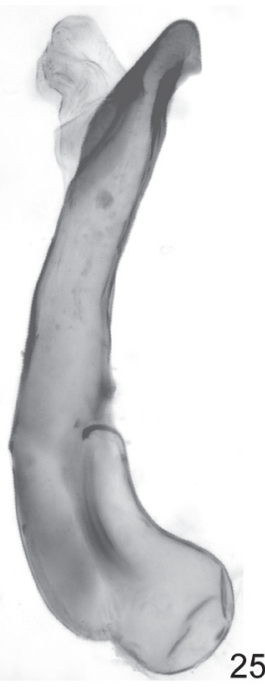

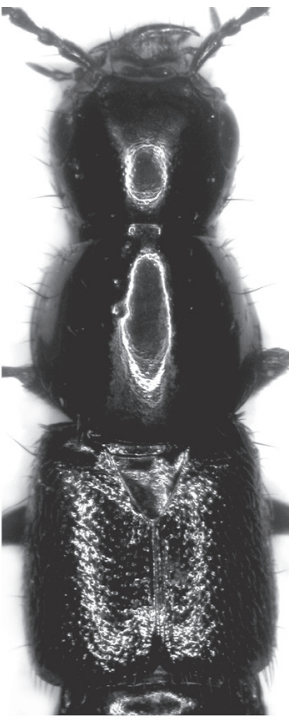

21

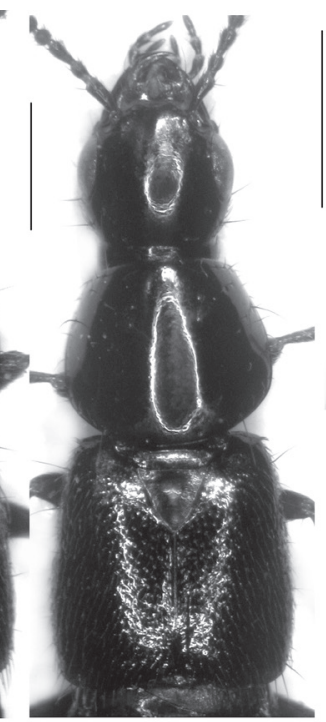

22

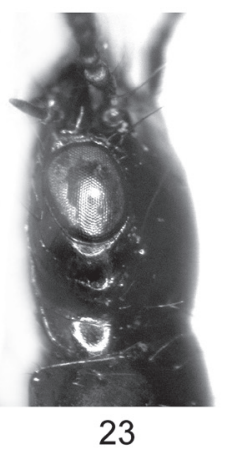

\section{3}

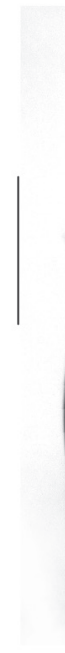

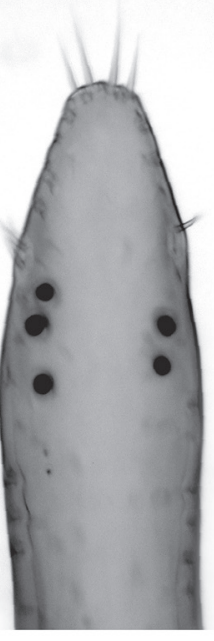

28

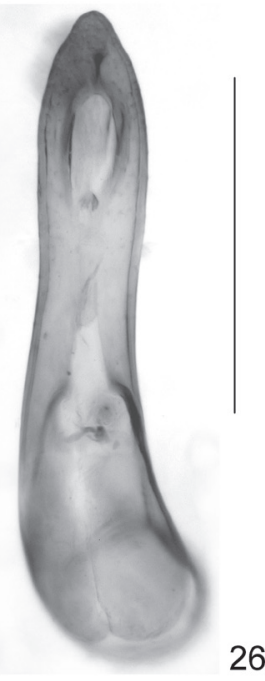

26
27

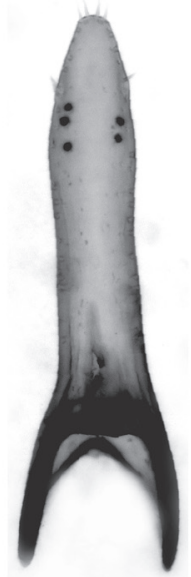

Figs 20-28: Quedius apfeli sp. n.: ơ habitus (20); ơ forebody (21); ㅇ forebody (22); head in lateral view (23); antenna (24); median lobe of aedeagus in lateral and in ventral view (25-26); paramere (27); apex of paramere (28). Scale bars: 20-24: $1.0 \mathrm{~mm}$; 25-27: $0.5 \mathrm{~mm}$; 28: $0.1 \mathrm{~mm}$.

External characters (Figs 20-24) as in Q. cruentus (OLIVIER, 1795), distinguished only as follows: Coloration of whole body blackish (similar to $Q$. nigrocaeruleus), except for the dark brown tarsi and external faces of the tibiae. Micropuncturation of pronotum slightly more distinct. Abdomen with more pronounced puncturation.

$\sigma^{\star}$ : posterior margin of sternite VIII as in Q. cruentus with rather shallow broadly concave excision; aedeagus with median lobe somewhat asymmetric, subapically not dentate (best seen in lateral view), and slightly less dilated subapically in ventral view (Figs 25-26); paramere apically narrowly convex and with 4-5 peg setae (Figs 27-28). 


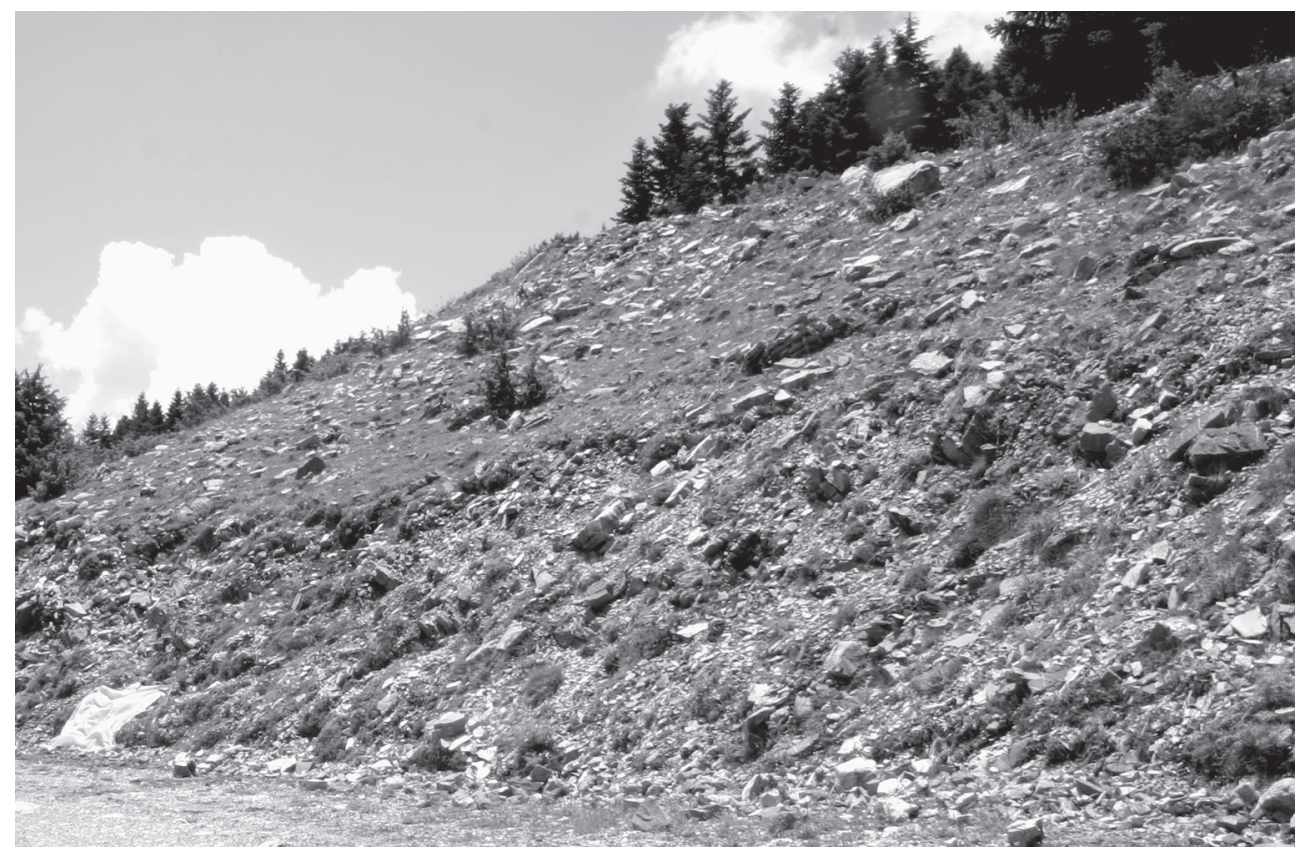

Fig. 29: Locality where five paratypes of Quedius endogeus sp. n. were found; the subterranean traps were placed in the calcareous roadside slope (photo: P. M. Giachino \& D. Vailati).

\section{Comparative notes:}

From the similarly coloured Q. nigrocaeruleus, Q. apfeli is readily distinguished by the shorter antennae with more strongly transverse preapical antennomeres, the slightly larger eyes, the absence of an additional puncture near the temporal puncture on the head, the much sparser puncturation of the postero-lateral parts of the head, the more slender tarsi, and by the different morphology of the aedeagus. In external and in the male sexual characters the new species is most similar to Q. cruentus, a highly variable species (especially in coloration). However, in numerous specimens examined from Central Europe, Italy, and Greece, at least the antennal base and the posterior margins of the posterior abdominal segments are reddish (even in dark-coloured specimens), the median lobe of the aedeagus is always distinctly dentate subapically, and the paramere is apically weakly to distinctly concave (not convex) and has 6-12 peg setae. Also, interspecific aedeagal character divergence is not pronounced in some other species allied to Q. cruentus either, e. g. Q. aetolicus. These findings suggest that the material from Cyprus represents a distinct species rather than a morphological variation of $Q$. cruentus.

Etymology: The species is dedicated to Wolfgang Apfel, Eisenach, who collected the holotype, the first mature male that became available for examination.

\section{Distribution and bionomics:}

The species is currently known only from Cyprus. The holotype was collected in an orchard, a female paratype in a stream valley. The male paratype collected in April is slightly teneral, suggesting that pre-imaginal development takes place during winter. 


\section{Acknowledgements}

I am most grateful to the colleagues indicated in the material section for arranging a loan of material under their care. In particular, I wish to thank Dr. Pier Mauro Giachino and Wolfgang Apfel for the generous gift of the holotypes of Q. endogeus and Q. apfeli, respectively. Dr. Alexey Solodovnikov, Copenhagen, provided helpful and critical comments on an earlier draft of the manuscript. Benedikt Feldmann proof-read the manuscript.

\section{References}

Assing, V. 2004: New species and records of Staphylinidae from Greece (Insecta: Coleoptera). - Linzer biologische Beiträge 36 (2): 593-613.

Assing, V. 2006: New species and records of Staphylinidae from Greece, with two new synonymies (Insecta: Coleoptera). - Linzer biologische Beiträge 38 (1): 333-379.

Assing, V. \& Wunderle, P. 2001: On the Staphylinidae of Greece. II. New species and new records from central and northern Greece (Insecta: Coleoptera). - Linzer biologische Beiträge 33 (1): 103-136.

Coiffart, H. 1978: Coléoptères staphylinides de la région paléartique [sic] occidentale. III. Sous famille Staphylininae, Tribu Quediini. Sous famille Paederinae, Tribu Pinophilini. - Supplément à la Nouvelle Revue d'Entomologie 8 (4): 364 pp.

Herman, L. H. 2001: Catalog of the Staphylinidae (Insecta: Coleoptera). 1758 to the end of the second millennium. Volumes I-VII. - Bulletin of the American Museum of Natural History 265: 4218 pp.

Reitter, E. 1900: Neue Coleopteren aus Europa, den angrenzenden Ländern, russisch Asien und der Mongolei. - Deutsche Entomologische Zeitschrift 1899: 273-281.

Smetana, A. 2004: Staphylinidae, subtribe Quediina Kraatz, 1857. - In: Löbl, I. \& Smetana, A. (eds.), Catalogue of Palaearctic Coleoptera. II. Hydrophiloidea-Histeroidea-Staphylinoidea. - Apollo Books, Stenstrup, 653-671.

Solodovnikov, A. Y. 2005: New and little known species of Quedius from West Palaearctic. - Zootaxa 902: $1-13$.

Solodovnikov, A. Y. 2006: Revision and phylogenetic assessment of Afroquedius gen. nov. from South Africa: toward new concepts of the genus Quedius, subtribe Quediina and reclassification of the tribe Staphylinini (Coleoptera: Staphylinidae: Staphylininae). - Annals of the Entomological Society of America 99: 1064-1084.

Author's address:

Dr. Volker Assing

Gabelsbergerstr. 2

30163 Hannover

Germany

e-mail: vassing.hann@t-online.de
Subject editor:

A. Solodovnikov 